\title{
EVALUATION OF METATARSAL RELATIONSHIPS IN THE BIOMECHANICS OF 332 NORMAL FEET USING THE METHOD OF MEASURING RELATIVE LENGTHS
}

Rui Barrôco', Caio Nery², Gabriela Favero ${ }^{3}$, Renan Mombach ${ }^{4}$, Oswaldo Nascimento ${ }^{5}$, Silvia Jorge ${ }^{5}$, Marina Monteiro 5 , Letícia Diedrichs ${ }^{6}$, Felipe Abreu ${ }^{7}$

\section{ABSTRACT}

Objective: To identify the mean normal length of the metatarsals and the most common metatarsal formulas through a simple measurement method, thereby providing surgeons with data for planning treatment on symptomatic individuals with biometric abnormalities of the foot. Methods: We evaluated and measured dorsoplantar weight-bearing radiographs of normal adult feet (83 males and 83 females). Results: We found relative mean lengths for metatarsus I of $125.4 \mathrm{~mm}$ for males and $115.1 \mathrm{~mm}$ for females; for metatarsus II, $127.8 \mathrm{~mm}$ for males and $117.3 \mathrm{~mm}$ for females; for metatarsus III, $123.4 \mathrm{~mm}$ for males and 113.5 $\mathrm{mm}$ for females; for metatarsus IV, $114.2 \mathrm{~mm}$ for males and
$105.3 \mathrm{~mm}$ for females; for metatarsus $\mathrm{V}, 99.5 \mathrm{~mm}$ for males and $91.7 \mathrm{~mm}$ for females. The mean forefoot width was 87.1 $\mathrm{mm}$ for males and $80.8 \mathrm{~mm}$ for females. Conclusion: Feet with index minus occurred most frequently in both sexes, although all three metatarsal formulas can be considered to be normal patterns. The mean normal pattern for males and females respectively was the following: metatarsus I 2.4 $\mathrm{mm}$ and $2.2 \mathrm{~mm}$ shorter than metatarsus II; metatarsus III $4.4 \mathrm{~mm}$ and $3.8 \mathrm{~mm}$ shorter than metatarsus II; metatarsus IV $9.2 \mathrm{~mm}$ and $8.2 \mathrm{~mm}$ shorter than metatarsus III; metatarsus V $14.7 \mathrm{~mm}$ and $13.6 \mathrm{~mm}$ shorter than metatarsus IV.

Keywords - Metatarsal Bones; Adult; Body Weights and Measures

\section{INTRODUCTION}

Many authors have affirmed that there is a high frequency of localized disorders in the feet ${ }^{(1-4)}$. In the normal population, it has been estimated that $70 \%$ of all individuals have or will have at least one episode of pain in the forefoot region during their lives ${ }^{(5)}$. If it is observed that the metatarsal lengths obey a standard relationship in individuals with pain-free static and dynamic functions, it can be concluded that there is a high likelihood that breaking this pattern will give rise to biomechanical changes. In up to
$92 \%$ of such pathological conditions, abnormalities of metatarsal positioning are thought to be related as etiological factors ${ }^{(1,6)}$.

We did not find in the literature any studies that focused on the normal mean length relationship between the metatarsals. For this reason, we did not observe any consensus with regard to choosing the best surgical alternative for use in treating metatarsal pain, especially when the procedure is carried out by means of osteotomy, which is still done empirically and without any scientific basis today. For

1. PhD. Professor and Head of the Foot Medicine and Surgery Sector, ABC School of Medicine, Santo André, SP, Brazil.

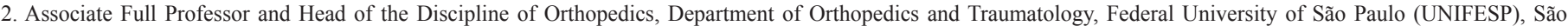
Paulo, SP, Brazil.

3. Orthopedist and former Trainee in the Foot Medicine and Surgery Sector, ABC School of Medicine, Santo André, SP, Brazil.

4. Orthopedist and former Specialization Resident in the Foot Medicine and Surgery Sector, ABC School of Medicine, Santo André, SP, Brazil.

5. Orthopedist in the Foot Medicine and Surgery Sector, ABC School of Medicine, Santo André, SP, Brazil.

6. Trainee Orthopedist (fourth-year Specialization Resident) in the Foot Medicine and Surgery Sector, ABC School of Medicine, Santo André, SP, Brazil

7. Resident Physician (third-year) in the Orthopedics Service, ABC School of Medicine, Santo André, SP, Brazil.

Work performed at Faculdade de Medicina do ABC - Santo André, SP, Brasil.

Correspondence: Rua Afonso Braz, 817, Vila Nova Conceição - 04511-011 - São Paulo, SP. E-mail: ruibarroco@uol.com.br

Work received for publication: June 14, 2010; accepted for publication: August 23, 2010.

The authors declare that there was no conflict of interest in conducting this work 
this reason, such surgical procedures may cause an iatrogenic pain transfer syndrome, which may result, for example, from excessive shortening of the osteotomized metatarsal.

In the light of this polemic, we sought to bring together information on length relationships between the metatarsals, with the initial aim of recognizing what the normal pattern is. From this information, it would be possible to predetermine the final size that the metatarsal should reach after carrying out osteotomy. Our objective was to create a simple and easily reproducible method for measuring the forefoot in order to ascertain the most frequent metatarsal formula.

\section{METHODS}

Our sample was composed of 166 individuals aged 25 to 50 years who did not have any previous or current complaints relating to their feet. There were 83 men (mean age of 35 years) and 83 women within the same age group (mean of 36 years), coming from the outpatient clinics of the orthopedics sector of Mario Covas State Hospital, in Santo André, thus totaling 332 feet evaluated. We did not make any distinction regarding ethnic group.

These volunteers underwent simple radiography on both feet, while bearing the body weight, in dorsoplantar view. We applied between $40 \mathrm{kV}$ and 60 $\mathrm{kV}$, with exposure of between $2 \mathrm{mAs}$ and $10 \mathrm{mAs}$. The basic requirement was to have a clear radiographic image of the middle and forefoot. The beam was angled at $15^{\circ}$ in relation to the vertical plane, in the cranial direction, as suggested by the great majority of authors, and a film holder measuring $24 \mathrm{~cm}$ x $30 \mathrm{~cm}$ was used $^{(7-12)}$. During image acquisition, the subject remained in an upright standing position, with equal weight distribution between the feet, and the beam focus was centered between the navicular bones ${ }^{(7,13)}$. The distance from the beam focus to the film holder was $80 \mathrm{~cm}^{(13)}$.

The relative lengths of the five metatarsals of each foot were measured. From a straight line over the Chopart joint (talonavicular and calcaneocuboid), tangential to the most medial and proximal points of the navicular bone and going as far as the lateral congruence point between the calcaneal and cuboid bone, we drew perpendicular straight lines to the most distal point of the head of each metatarsal, and measured these distances in millimeters (Figure 1). The width of the forefoot was measured as the distance between two straight lines perpendicular to the Chopart joint, tangential to the most medial and most lateral points of the heads of first and fifth metatarsals, respectively (Figure 2).

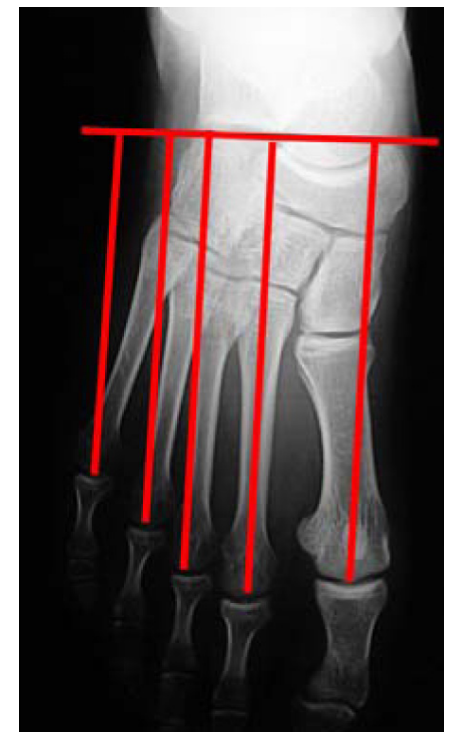

Figure 1 - Metatarsal length measurement method.

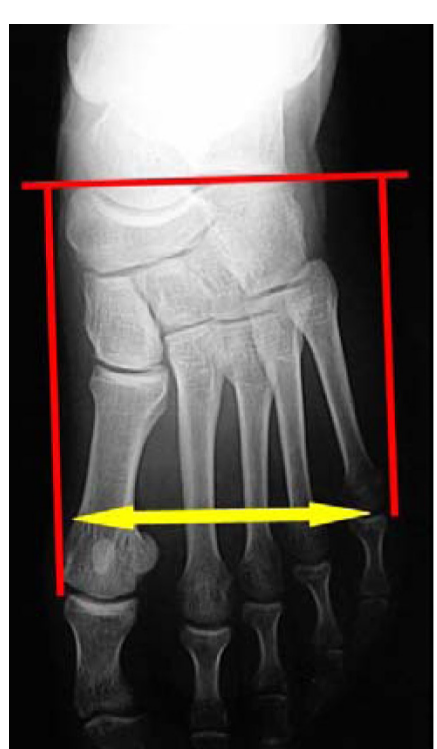

Figure 2 - Forefoot width measurement method.
In the statistical analysis, the quantitative variables were represented by the mean, standard deviation (SD) and maximum and minimum values, while the qualitative variables were represented by absolute frequencies (n) and relative frequencies (\%).

To compare the right and left sides in relation to the parameters evaluated, Student's t test for independent samples was used, paired in groups of men and women separately. From the measurements obtained (length of the second metatarsal and width of the forefoot), the forefoot width/metatarsal II (FW/MII) index was calculated, and the correlation between age and the indices was evaluated using Pearson's correlation coefficient (r), separately for the groups of male and female feet. The samples of male and female feet (evaluated separately) were divided into age groups and these were compared in relation to the indices by means of the analysis of variance technique (ANOVA). Any differences were then located by means of the Tukey multiple comparisons test. It should be noted that this analysis had to be done because 
of the small numbers of feet seen in some age groups. The significance level of $0.05(\mathrm{a}=5 \%)$ was used, and descriptive levels (p) lower than this value were taken to be significant.

\section{RESULTS}

\section{Comparison between the right and left sides}

Tables 1 and 2 present the means and standard deviations for the parameters evaluated in the right and left feet, for both sexes, and the respective comparisons. From these results, the two sides were independent and therefore for the remaining evaluations on these parameters, the samples were duplicated. In relation to the side, the feet were compared regarding all the measurements obtained, and the results found were: 1. Both in the group of 83 pairs of male feet and in the group of 83 pairs of female feet, no statistically significant difference was found between the means of the measurements on the right and left feet, for any of the parameters evaluated ( $p>0.05$ in all the comparisons).

Table 1 - Mean and standard deviation of metatarsal size in the male subjects.

\begin{tabular}{|c|c|c|c|c|}
\hline \multicolumn{5}{|c|}{ Parameter } \\
\hline & $\begin{array}{l}\text { Right foot } \\
\text { (SD) } \\
(n=83)\end{array}$ & $\begin{array}{l}\text { Left foot } \\
\qquad(\mathrm{SD}) \\
(\mathrm{n}=83)\end{array}$ & $\begin{array}{l}\text { Difference } \\
\text { between right } \\
\text { and left foot } \\
\text { (SD) }\end{array}$ & $\begin{array}{c}\text { Paired } \\
\text { Student's } \\
\text { t test }\end{array}$ \\
\hline M I & $125.20(8.42)$ & $125.60(8.18)$ & $-0.40(2.27)$ & $p=0.114$ \\
\hline M II & 127.75 (8.37) & $127.87(8.14)$ & $-0.12(1.89)$ & $p=0.563$ \\
\hline M III & $123.17(8.23)$ & $123.54(7.94)$ & $-0.37(2.08)$ & $p=0.106$ \\
\hline M IV & $114.16(7.93)$ & $114.28(7.59)$ & $-0.12(2.49)$ & $p=0.661$ \\
\hline M V & 99.46 (8.19) & $99.64(7.82)$ & $-0.18(3.08)$ & $p=0.595$ \\
\hline $\begin{array}{l}\text { Forefoot } \\
\text { width }\end{array}$ & $86.80(5.75)$ & $87.31(5.52)$ & $-0.52(3.04)$ & $p=0.125$ \\
\hline $\begin{array}{c}\text { Forefoot } \\
\text { width/MII } \\
\text { index }\end{array}$ & $0.681(0.050)$ & $0.684(0.046)$ & $-0.003(0.024)$ & $p=0.235$ \\
\hline
\end{tabular}

Table 2 - Mean and standard deviation of metatarsal size in the female subjects.

\begin{tabular}{|c|c|c|c|c|}
\hline \multicolumn{5}{|c|}{ Parameter } \\
\hline & \begin{tabular}{|} 
Right side \\
(SD) \\
$(n=83)$
\end{tabular} & $\begin{array}{l}\text { Left side } \\
\qquad(\mathrm{SD}) \\
(\mathrm{n}=83)\end{array}$ & $\begin{array}{l}\text { Difference } \\
\text { between right } \\
\text { and left foot } \\
\text { (SD) }\end{array}$ & $\begin{array}{c}\text { Paired } \\
\text { Student's t } \\
\text { test }\end{array}$ \\
\hline M I & $\begin{array}{c}115.02 \\
(7.22)\end{array}$ & $115.23(7.70)$ & $-0.20(1.72)$ & $p=0.280$ \\
\hline M II & $\begin{array}{c}117.53 \\
(7.24)\end{array}$ & $117.58(7.51)$ & $-0.05(1.71)$ & $p=0.798$ \\
\hline M III & $\begin{array}{l}113.51 \\
(7.13)\end{array}$ & $113.41(7.40)$ & $0.10(2.02)$ & $p=0.664$ \\
\hline M IV & $\begin{array}{l}105.46 \\
(7.12)\end{array}$ & $105.22(7.47)$ & $0.24(2.36)$ & $p=0.354$ \\
\hline M V & $\begin{array}{l}91.70 \\
(7.26)\end{array}$ & 91.66 (7.71) & $0.04(3.42)$ & $p=0.924$ \\
\hline $\begin{array}{l}\text { Forefoot } \\
\text { width }\end{array}$ & $\begin{array}{l}80.92 \\
(4.77)\end{array}$ & $80.72(4.56)$ & $0.19(2.43)$ & $p=0.472$ \\
\hline $\begin{array}{c}\text { Forefoot } \\
\text { width/MII } \\
\text { indexl }\end{array}$ & $\begin{array}{c}0.690 \\
(0.045)\end{array}$ & $0.688(0.044)$ & $0.002(0.022)$ & $p=0.463$ \\
\hline
\end{tabular}

Source: HRM-LA; HGF-LA. M - metatarsal length in millimeters SD - standard deviation (n) - number of subjects.

\section{Comparison between males and females}

Table 3 presents the means, standard deviations and ranges (maximum and minimum values) of the parameters evaluated, between the feet of the male and female individuals, and the respective comparisons. The feet were compared in relation to all the measurements obtained and the results found were:

1 . There was a statistically significant difference between the groups of 166 male feet and 166 female feet, in relation to the mean measurements of metatarsal length and forefoot width $(\mathrm{p}<0.001$ in all the comparisons), in which the means for the group of male feet were significantly greater than those for the group of female feet.

2. There was no statistically significant difference between the male and female groups in relation to the means for the FW/MII index $(p=0.215)$.

\section{Relationship between age and FW/MII index}

Figure 3 shows the dispersion of the FW/MII index in relation to the ages of our sample, according to sex. Table 4 details the values found. In the analysis on the correlation between age and the FW/MII index, the results found were: 
Tabela 3 - Médias (dp) e variações (valores mínimos e máximos) dos parâmetros avaliados nos pés masculinos e femininos e respectivas comparações.

\begin{tabular}{|c|c|c|c|}
\hline \multicolumn{4}{|c|}{ Sexo } \\
\hline Parameters & $\begin{array}{c}\text { Male (SD) } \\
(n=166)\end{array}$ & $\begin{array}{c}\text { Female (SD) } \\
\quad(n=166)\end{array}$ & $\begin{array}{c}\text { Independent } \\
\text { Student's t } \\
\text { test }\end{array}$ \\
\hline M I & $\begin{array}{c}125.40(8.28) \\
100-153\end{array}$ & $\begin{array}{c}115.13(7.44) \\
99-133\end{array}$ & $p<0.001$ * \\
\hline M II & $\begin{array}{c}127.81(8.23) \\
102-153\end{array}$ & $\begin{array}{c}117.55(7.35) \\
102-137\end{array}$ & $\mathrm{p}<0.001$ * \\
\hline M III & $\begin{array}{c}123.36(8.06) \\
99-146\end{array}$ & $\begin{array}{c}113.46(7.25) \\
98-132\end{array}$ & $p<0.001$ * \\
\hline M IV & $\begin{array}{c}114.22(7.74) \\
94-135\end{array}$ & $\begin{array}{c}105.34(7.28) \\
91-124\end{array}$ & $p<0.001$ * \\
\hline M V & $\begin{array}{c}99.55(7.98) \\
81-120\end{array}$ & $\begin{array}{c}91.68(7.47) \\
75-117\end{array}$ & $p<0.001$ * \\
\hline Forefoot width & $\begin{array}{c}87.05(5.63) \\
70-101\end{array}$ & $\begin{array}{c}80.82(4.65) \\
66-95\end{array}$ & $p<0.001$ * \\
\hline $\begin{array}{l}\text { Forefoot width/MII } \\
\text { index }\end{array}$ & $\begin{array}{l}0.683(0.048) \\
0.529-0.832\end{array}$ & $\begin{array}{l}0.689(0.044) \\
0.595-0.804\end{array}$ & $p=0.215$ \\
\hline
\end{tabular}

$\overline{\text { Source: HRM-LA; HGF-LA. - M - metatarsal - mean length, min - max - SD - standard }}$ deviation - (n) - number of subjects.

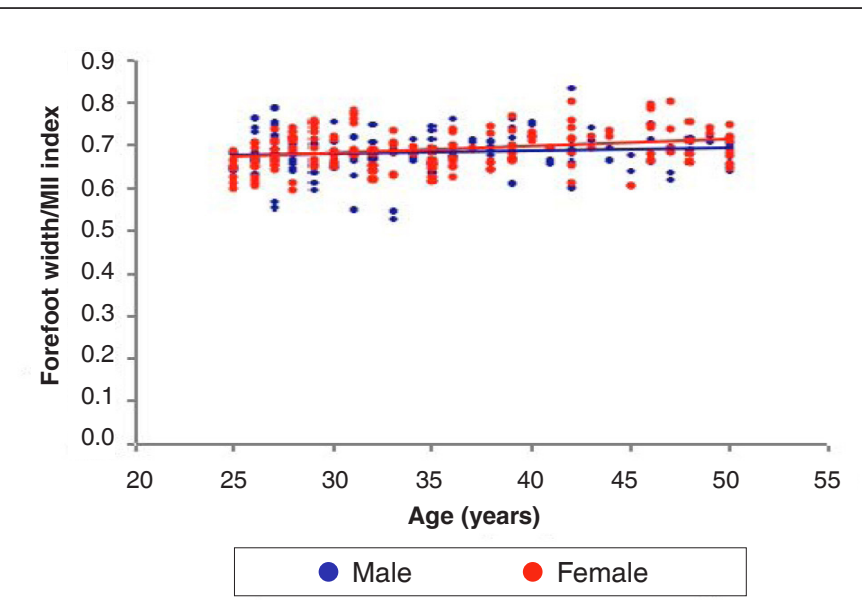

Figure 3 - Dispersion of the forefoot width/MII index in relation to the subjects' ages divided according to sex.

In the group of male feet, there was a positive but non-significant correlation between age and the index $(r=0.11 ; p=0.154)$. In the group of female feet, there was a significant positive correlation between age
Table 4 - Comparison between age groups in relation to the index, for both sexes.

\begin{tabular}{|c|c|c|c|c|c|c|}
\hline \multirow{3}{*}{$\begin{array}{l}\text { Age } \\
\text { group }\end{array}$} & \multicolumn{6}{|c|}{ Sex } \\
\hline & \multicolumn{3}{|c|}{ Male } & \multicolumn{3}{|c|}{ Female } \\
\hline & $\begin{array}{l}\text { Mean } \\
\text { (SD) }\end{array}$ & mín - máx & $\mathbf{n}$ & $\begin{array}{l}\text { Mean } \\
\text { (SD) }\end{array}$ & mín - máx & $\mathbf{n}$ \\
\hline $25-26$ & $\begin{array}{c}0.678 \\
(0.041)\end{array}$ & $0.633-0.766$ & 20 & $\begin{array}{c}0.642 \\
(0.026)\end{array}$ & $0.598-0.686$ & 10 \\
\hline $27-28$ & $\begin{array}{c}0.693 \\
(0.054)\end{array}$ & $0.554-0.789$ & 26 & $\begin{array}{c}0.669 \\
(0.034)\end{array}$ & $0.606-0.739$ & 20 \\
\hline $29-30$ & $\begin{array}{c}0.661 \\
(0.041)\end{array}$ & $0.594-0.758$ & 18 & $\begin{array}{c}0.687 \\
(0.040)\end{array}$ & $0.595-0.722$ & 14 \\
\hline $31-32$ & $\begin{array}{c}0.675 \\
(0.044)\end{array}$ & $0.551-0.750$ & 16 & $\begin{array}{c}0.705 \\
(0.037)\end{array}$ & $0.653-0.761$ & 22 \\
\hline $33-34$ & $\begin{array}{c}0.657 \\
(0.064)\end{array}$ & $0.529-0.713$ & 10 & $\begin{array}{c}0.689 \\
(0.051)\end{array}$ & $0.619-0.783$ & 20 \\
\hline $35-36$ & $\begin{array}{c}0.684 \\
(0.040)\end{array}$ & $0.615-0.763$ & 16 & $\begin{array}{c}0.685 \\
(0.009)\end{array}$ & $0.678-0.697$ & 4 \\
\hline $37-38$ & $\begin{array}{c}0.693 \\
(0.022)\end{array}$ & $0.649-0.713$ & 8 & $\begin{array}{c}0.666 \\
(0.036)\end{array}$ & $0.617-0.739$ & 14 \\
\hline $39-40$ & $\begin{array}{c}0.704 \\
(0.052)\end{array}$ & $0.608-0.763$ & 12 & $\begin{array}{c}0.690 \\
(0.035)\end{array}$ & $0.643-0.769$ & 18 \\
\hline $41-42$ & $\begin{array}{c}0.692 \\
(0.081)\end{array}$ & $0.600-0.832$ & 10 & $\begin{array}{c}0.711 \\
(0.042)\end{array}$ & $0.613-0.802$ & 16 \\
\hline $43-44$ & $\begin{array}{c}0.703 \\
(0.032)\end{array}$ & $0.664-0.742$ & 4 & $\begin{array}{c}0.688 \\
(0.058)\end{array}$ & $0.607-0.748$ & 8 \\
\hline $45-46$ & $\begin{array}{c}0.692 \\
(0.042)\end{array}$ & $0.641-0.752$ & 8 & $\begin{array}{c}0.732 \\
(0.048)\end{array}$ & $0.661-0.804$ & 12 \\
\hline $47-48$ & $\begin{array}{c}0.684 \\
(0.037)\end{array}$ & $0.620-0.719$ & 8 & $\begin{array}{c}0.724 \\
(0.017)\end{array}$ & $0.709-0.748$ & 4 \\
\hline $49-50$ & $\begin{array}{c}0.685 \\
(0.027)\end{array}$ & $0.642-0.721$ & 10 & $\begin{array}{c}0.667 \\
(0.016)\end{array}$ & $0.649-0.684$ & 4 \\
\hline
\end{tabular}

Source: HRM-LA; HGF-LA - SD - standard deviation (n) - number of subjects.

and the index $(\mathrm{r}=0.27 ; \mathrm{p}<0.001)$. Both correlation values were considered to be very low and would be subject to large numbers of errors in any attempt to predict the index using age alone.

The different age groups among the male feet were compared in relation to the index, and no statistically significant difference was found between them $(\mathrm{p}=$ $0.401)$. On the other hand, there was a statistically significant difference between the age groups of the female feet, in relation to the index $(p<0.001)$. The differences encountered did not show any tendency towards increases or decreases in the index as a function of age variation, and they were as follows: 
1. The group of 25-26 years of age, with the lowest mean, was significantly different from the groups of 31-32 years, $41-42$ years, $45-46$ years and $47-48$ years, which presented the highest means.

2. The group of 27-28 years, with the third lowest mean, differed significantly from the group of $45-46$ years, which presented the highest mean.

3 . The group of 37-38 years, with the second lowest mean, was significantly different from the group of 45-46 years, which presented the highest mean.

\section{Metatarsal formula}

Tables 5 and 6 present the classification patterns for the metatarsal formula found in the left and right feet, for each sex. In the group of 166 male feet, 119 (71.7\%) were Index minus, 31 (18.7\%) Index plus and $16(9.6 \%)$ Index plus minus; while in the group of 166 female feet, $123(74.1 \%)$ were Index minus, $30(18.1 \%)$ Index plus and $13(7.8 \%)$ Index plus minus. In evaluating the metatarsal formula, there was discordance in the classification between the feet of the same individual, in $16.2 \%$ of the 166 pairs of feet evaluated: $18.0 \%$ of the 83 male pairs and $14.4 \%$ of the female pairs.

Table 7 elucidates the metatarsal formulas found in our survey. The order of metatarsal formulas II $>$ I $>$ III $>$ IV $>$ V was the most common. We found Index minus in $71.7 \%$ of the men and in $74.1 \%$ of the women.

Table 5 - Classification patterns for metatarsal formulas found in the left and right feet among male subjects.

\begin{tabular}{c|c|c}
\hline Right foot & Left foot & N (\%) \\
\hline Index minus & Index minus & $54(65.1)$ \\
\hline Index minus & Index plus & $2(2.4)$ \\
\hline Index minus & Index plus minus & $3(3.6)$ \\
\hline Index plus & Index minus & $3(3.6)$ \\
\hline Index plus & Index plus & $11(13.3)$ \\
\hline Index plus minus & Index minus & $2(2.4)$ \\
\hline Index plus minus & Index plus & $5(6.0)$ \\
\hline Index plus minus & Index plus minus & $3(3.6)$ \\
\hline \multicolumn{2}{c|}{ Total } & \\
\hline
\end{tabular}

Source: HRM-LA; HGF-LA - (n) - number of subjects.
Table 6 - Classification patterns for metatarsal formulas found in the left and right feet among female subjects.

\begin{tabular}{c|c|c}
\hline Right foot & Left foot & $\mathbf{n}(\%)$ \\
\hline Index minus & Index minus & $57(68.7)$ \\
\hline Index minus & Index plus & $2(2.4)$ \\
\hline Index minus & Index plus minus & $3(3.6)$ \\
\hline Index plus & Index minus & $1(1.2)$ \\
\hline Index plus & Index plus & $12(14.5)$ \\
\hline Index plus & Index plus minus & $2(2.4)$ \\
\hline Index plus minus & Index minus & $3(3.6)$ \\
\hline Index plus minus & Index plus & $1(1.2)$ \\
\hline Index plus minus & Index plus minus & $2(2.4)$ \\
\hline
\end{tabular}

Source: HRM-LA; HGF-LA - (n) - number of subjects.

Table 7 - Metatarsal formulas encountered.

\begin{tabular}{|c|c|c|c|}
\hline $\begin{array}{l}\text { Male subjects } \\
\text { (M) }\end{array}$ & (n) & $\begin{array}{l}\text { Female subjects } \\
\text { (M) }\end{array}$ & (n) \\
\hline$\|>|>| I|>| V>V$ & 57 & $I I>|>I I|>\mid V>V$ & 57 \\
\hline$I|>| I \mid>I>I V>V$ & 44 & $\mathrm{II}>\mathrm{III}>\mathrm{I}>\mathrm{IV}>\mathrm{V}$ & 38 \\
\hline$|>||>| I|>| V>V$ & 29 & $|>||>|||>\mid V>V$ & 30 \\
\hline$I=I|>I I|>I V>V$ & 15 & $I I>I=I I \mid>I V>V$ & 24 \\
\hline$|I>I=| I \mid>I V>V$ & 14 & $\mathrm{I}=\mathrm{II}>\mathrm{III}>\mathrm{IV}>\mathrm{V}$ & 13 \\
\hline$I I=I I \mid>I>I V>V$ & 3 & $I I=I I \mid>I>I V>V$ & 4 \\
\hline$I I=I I \mid>I=I V>V$ & 1 & & \\
\hline $\mathrm{I}=\mathrm{II}=\mathrm{III}>\mathrm{IV}>\mathrm{V}$ & 1 & & \\
\hline$|>||=| I|>| V>V$ & 2 & & \\
\hline Total & 166 & & 166 \\
\hline
\end{tabular}
$\mathrm{V}-$ numbers of the five metatarsi.

Table 8 presents the means for the metatarsal measurements, for both sexes. From this table, the normal mean pattern found was that metatarsal I was $2.4 \mathrm{~mm}$ smaller than II in the men and $2.2 \mathrm{~mm}$ in the women; III was $4.4 \mathrm{~mm}$ smaller than II in the men and 3.8 
$\mathrm{mm}$ in the women; IV was $9.2 \mathrm{~mm}$ smaller than III in the men and $8.2 \mathrm{~mm}$ in the women; and $\mathrm{V}$ was $14.7 \mathrm{~mm}$ smaller than IV in the mean and $13.6 \mathrm{~mm}$ in the women.

Table 8 - Mean measurements of the metatarsi in both sexes $(\mathrm{mm})$.

\begin{tabular}{c|c|c|c}
\hline & \multicolumn{2}{c|}{ Male } & Female \\
\hline MI & \multicolumn{2}{|c|}{125.4} & 115.1 \\
\hline MII & 127.8 & 117.3 & \\
\hline MIII & 123.4 & 113.5 & 105.3 \\
\hline MIV & \multicolumn{2}{|c|}{114.2} \\
\hline MV & \multicolumn{2}{|c|}{99.5} \\
\hline Source: HRM-LA; HGF-LA - (n) - number of subjects M - metatarsal length.
\end{tabular}

\section{DISCUSSION}

Although many studies have not placed any emphasis on comparisons between the left and right feet, we found that their measurements were statistically similar, which thus made it possible for them to be grouped as a single sample. On the other hand, this could not be done between the sexes.

We found a variety of measurement methods in the literature, but none of them had very good reproducibility, and some did not take all five metatarsals into account. For example, some authors measured the angle formed by the heads of metatarsals I, II and $\mathrm{V}$, but disregarded the measurements of III and IV $^{(5,14-16)}$. Lerch ${ }^{(17)}$ measured the angle formed by the axis of the metatarsal bone under examination and the straight line joining the anterior extremity of its head to the same point on its side, thus requiring instruments to measure the angle, as well as not making a measurement prediction on the normal bone. Other authors have believed that the foot should be evaluated considering a step angle (Fick) of $15^{\circ}$ to $18^{\circ}$, but this not only does not give the standard angular precision but also creates the need for appropriate instruments $^{(6,18-21)}$. Dragonetti and Romanòl ${ }^{(22)}$ took the static axis of the foot as their reference. This is determined by joining the midpoint of the bimalleolar distance to the center of the metatarsophalangeal joint of the second toe. This also depends on a normal measurement of the talonavicular angle, which is usually abnormal in high-arch and flat feet. We could see that because of this great variability, it would be difficult to correlate the published results.

Our method is simple, easy to use, subject to little variation and minimally subject to errors, and does not require a transfer device or goniometry.

The foot grows until the age of 15 years in women and 17 years in men ${ }^{(23)}$. Fusion of the epiphysis takes place before two decades of life are completed $^{(10,15,24-28)}$. We sought to evaluate individuals between the ages of 25 and 50 years, in order to avoid having immature feet in our sample and thus to avoid any possible type of bias.

Radiographic standardization is the basis for studying the biomechanical conditions of the foot ${ }^{(29,30)}$. We observed that Keim and Ritchie ${ }^{(31)}$ drew attention to the importance of carrying out radiographic examination on the feet with loading applied and in the two usual projections (dorsoplantar and lateral). Moreover, Shereff et $\mathrm{al}^{(32)}$ made a comparison between examinations with and without loading and concluded that significant widening of the forefoot occurred in $90 \%$ of the cases, and that the length of metatarsal bone I increased in $95 \%$ of the cases. The great variability in the measurements led us to choose a method with load-bearing, since this reproduces the situation in which complaints generally arise.

Also in relation to radiographic examinations, Fonseca Filho ${ }^{(33)}$ emphasized that the aim of having the incidence of the central beam between the feet at the level of the navicular bones was to achieve a final image in a single shot and with the same degree of distortion, both for the right side and for the left side. We believe that this method actually has advantages, because it exposes patients just once for performing radiography, and because it avoids single-foot load-bearing for patients with intense pain in their feet.

Despite wide-ranging discussion in many studies, the anatomical configuration that enables pain-free functioning of the foot has still not been well determined. Marques ${ }^{(34)}$ compared the feet of individuals of both sexes between different races and did not find any significant difference between their types. Honnart ${ }^{(35)}$ reported that the metatarsal bones are their relative lengths had an important role in achieving adequate load-bearing. According to Steitz, apud Barbieri and Federzoni $^{(36)}$, anterior load-bearing of the foot is done 
in $57 \%$ of the cases on the head of metatarsal I and in $20 \%$, on II, while in $17 \%$, it takes place on all the heads and in $6 \%$ there is no rule at all. In our study, we observed three metatarsal formulas in these normal feet.

The second metatarsal fits between the three cuneiform bones, which makes it relatively immobile in relation to the midfoot. It is generally the longest of the metatarsals. If the foot is not free to deviate laterally, the second metatarsal is overloaded at the time of toe push-off, with a weight that should be divided between this and the other metatarsals, which can be seen through the presence of a plantar callus in the region of its head ${ }^{(37)}$.

Surgical removal of the base of the proximal phalanx of the hallux creates instability of the medial longitudinal arch, consequent to injury of the plantar aponeurosis and breakdown of the mechanism for arch elevation. This diminishes the load that is sustained by the head of the first metatarsal, thus resulting is weight transfer to the heads of the smaller metatarsals. If the base of the proximal phalanx of any of the smaller toes is resected, a similar problem of instability occurs, but to a lesser degree.

Resection of the head of a metatarsal, except in cases of severe deformities in a rheumatic or diabetic foot, produces a similar problem because the mechanism for plantar arch elevation is destroyed through relative shortening of the radius. This also generates increased stress and formation of calluses on the plantar face of the adjacent metatarsal head (iatrogenic compensation metatarsalgia). This makes it clear that there is a standard relationship between the lengths of the metatarsals, and that when this relationship is broken, some type of pain is caused in the affected foot ${ }^{(37)}$.

Most authors have identified the presence of Index minus as the most common normal pattern ${ }^{(15,38-42)}$. This is in line with our results $(71.7 \%$ in the male group and $74.1 \%$ in the female group).

There is a consensus that metatarsal $\mathrm{V}$ is always smaller than metatarsal IV, and that IV is always smaller than the first three. This pattern was obtained in $100 \%$ of our sample.

Dragonetti and Romano ${ }^{(22)}$ and Marques and Napo$\mathrm{li}^{(43)}$ described the presence of ten metatarsal formulas in normal feet. We found nine formulas in the male sample and six in the female sample, and all the formulas seen among the females were present in the males.

Differences of up to $2 \mathrm{~mm}$, upwards or downwards, between metatarsals I and II are within normal occurrences $^{(19)}$. We also found a mean difference of $2 \mathrm{~mm}$ between the lengths of metatarsals I and II, although in one individual the difference reached $13 \mathrm{~mm}$.

\section{CONCLUSIONS}

1. Feet with Index minus predominated in both sexes, with three metatarsal formulas within the patterns of normality.

2. The mean normal pattern found was that metatarsal I was $2.4 \mathrm{~mm}$ smaller than II in the men and 2.2 $\mathrm{mm}$ in the women; III was $4.4 \mathrm{~mm}$ smaller than II in the men and $3.8 \mathrm{~mm}$ in the women; IV was $9.2 \mathrm{~mm}$ smaller than III in the men and $8.2 \mathrm{~mm}$ in the women; and $\mathrm{V}$ was $14.7 \mathrm{~mm}$ smaller than IV in the mean and $13.6 \mathrm{~mm}$ in the women.

\section{REFERENCES}

1. Du Vries HL, Inman JT. Surgery of the foot. 2nd ed. St. Louis: Mosby; 1965.

2. Giannestras NJ. Foot disorders. 2nd ed. Philadelphia: Lea \& Febiger; 1973.

3. Troncoso J, Viladot A Jr. Metatarsalgia. Rev Orthop Traumatol. 1965,;9:5-192.

4. Viladot A Jr. Exploración. In: Diez lecciones sobre patologia del pie. Barcelona: Toray;1979. p.41-63.

5. Almenar Benages L. Exploración radiográfica del pie. Med Esp. 1962;47:400-13.

6. Viladot-Perice A. Metatarsalgias, in patologia do antepé. 3a. ed. São Paulo: Rocca; 1987.

7. Chati Sobrinho J. Estudo anatomo-radiológico do arco anterior do pé. São Paulo: Faculdade de Ciências Médicas da Santa Casa de São Paulo; 1976.

8. Freiberger RH: Roentgen examination of the foot. Bull Hosp Spec Surg. $1961 ; 4: 20-3$

9. Hlavac HF. Differences in x-ray findings with varied positioning of the foot. J Am Podiatry Assoc. 1967;57(10):465-71.

10. Kleiger B, Greenspan A, Norman A. Roentgenographic examination of the normal foot and ankle. In: Jahss MH. Disorders of the foot. Philadelphia: Saunders; 1982. p. 116-38.
11. Machado GO. Estudo radiológico das relações de alguns parâmetros do primeiro metatarsiano em 420 pés normais. [tese]. Sorocaba: Pontifícia Universidade Católica de São Paulo; 1985.

12. Steel MW 3rd, Johnson KA, DeWitz MA, Ilstrup DM. Radiographic measurements of the normal adult foot. Foot Ankle. 1980;1(3):151-8.

13. Price GF. Metatarsus primus varus: including various clinicoradiologic feautres of the female foot. Clin Orthop Relat Res. 1979;(145): 217-23.

14. Gaunel C, Louyot P, Treheux A. [Radiological study of the pronation or supination deformities of the foot]. Rev Rhum Mal Osteoartic. 1971;28(10):591-8.

15. Meschan I. Radiology of the normal foot. Semin. Roentgenol. 1970;5(4): 327- 40.

16. Montagne J, Chevrot A, Chafetz N, Galmiche JM. Atlas of foot radiology. N. York: Masson; 1981.

17. Lerch H. Form of arch of metattarsal head. Z Orthop. 1949;78:157-60.

18. Chiappara P, Verrina F. [Plantar prints in podological practice]. Minerva Chir. 1977;32(8):487-90.

19. Weissman SD. Radiology of the foot. Baltimore: Williams \& Wilkins; 1983.

20. Ducroquet R. Marcha normal y patológica. Barcelona: Toray-Masson; 1972. 
21. Romeiro VA. Fórmulas do antepé. Amostragem das fórmulas digital e metatarsiana em um único grupo etário do sexo masculino [dissertação]. Rio de Janeiro: Faculdade de Medicina da Universidade Federal do Rio de Janeiro; 1989.

22. Dragonetti L, Romanò A. La formula metatarsale. [Metatarsal formula. Study of the arrangement and relations of metatarsal heads in the normal feet]. Chir Ital. 1968;20(2):300-10.

23. Ellis VH. A method of correcting metatarsus primus varus; preliminary report. J Bone Joint Surg Br. 1951;33(3):415-7.

24. Lelievre J. Patologia del pie. Barcelona: Toray-Masson; 1960.

25. Camp JD, Cilley E. Diagrammatic chart showing time of appearance of the various centers of ossification and period of union. Am J Roentgenol. 1931:26: 905.

26. Flecker H. Union of metatarsal epiphyses. Am J Roentgenol Radium Ther Nucl Med. 1952;68(1):37.

27. Lockart RD. Anatomy of the human Body. London: Faber and Faber; 1959.

28. O'Rahilly R, Gardner E, Gray DJ. The skeletal development of the foot. Clin Orthop. 1960;16:7-14.

29. Gamble FO, Yale I. Clinical foot roentgenology. Baltimore: Williams \& Wilkins; 1966.

30. Pisani G, Garneri L. L'indagine funzionale del piede. Chir Del Piede. 1980;4:1-16.

31. Keim HA, Ritchie GW. Weight-bearing roentgenograms in the evaluation of foot deformities. Clin Orthop Relat Res. 1970;70:133-6.

32. Shereff MJ, DiGiovanni L, Bejjani FJ, Hersh A, Kummer FJ. A comparison ofnonweight-bearing and weight-bearing radiographs of the foot. Foot Ankle. 1990;10(6):306-11.
33. Fonseca Filho FF. Fórmula metatarsal. Diferença entre as posições das terminações distais dos ossos metatarsais I e II e distribuição de frequência [dissertação]. São Paulo: Faculdade de Ciências Médicas da Santa Casa de São Paulo; 1987.

34. Marques J. Estudo radiográfico do antepé. Baseado em 360 pés adultos normais [tese]. São Paulo: Faculdade de Medicina da Universidade de São Paulo; 1991.

35. Honnart F. [Anatomy and physiology of the fore part of the foot]. Rev Chir Orthop Reparatrice Appar Mot. 1974;60(Suppl 2):107-12

36. Barbieri A, Federzoni F. [Metatarsalgias from flattening of the transverse vault. (Considerations on surgical treatment)]. Arch Putti Chir Organi Mov. 1966;21:134-50.

37. Mann RA, Poppen NK, O'Konski M. Amputation of the great toe. A clinical and biomechanical study. Clin Orthop Relat Res. 1988;(226):192-205.

38. Valenti V. Curso de podologia. In: Congresso Brasileiro de Medicina e Cirurgia do Pé. 2a. ed. Canela-Gramado (RS) Brasil, 1980. p. 1 e 7.

39. Maschas A. [Anatomy and physiology of the fore part of the foot. Radiological study]. Rev Chir Orthop Reparatrice Appar Mot. 1974;60(Suppl 2):131-6.

40. Cailliet R. Síndromes dolorosos - Pé e Tornozelo. São Paulo: Manole; 1975.

41. Harty M. Metatarsalgia. Surg Gynecol Obstet. 1973;136(1):105-6.

42. Du VRIES HL: Cirurgia del pie. México: Interamericana; 1960. p. 356.

43. Marques J, Napoli MM. Estudo radiográfico da fórmula metatarsal. Baseado em 360 pés de adultos normais das raças branca, negra e amarela. Rev Cubana Ortop Traumatol, $1987 ; 2(2): 24-8$. 